\title{
Influence of two native shrubs on goat nitrogen status
}

\author{
A. BOUTOUBA, J.L. HOLECHEK, M.L. GALYEAN, G. NUNEZ-HERNANDEZ, J.D. WALLACE, AND M. CARDENAS
}

\section{Abstract}

In vivo digestibility trials were conducted in metabolism stalls at New Mexico State University to evaluate the influence of leaves of true mountain mahogany (Cercocarpus montanus Raf.) and fourwing saltbush (Atriplex canescens [Pursh.] Nutt.) on nitrogen retention and digestibility by Angora goats. Each of the 2 shrubs were fed at $30 \%$ and $60 \%$ (air dry basis) of the diet along with prairie hay that was comprised mostly of blue grama (Bouteloua gracilis [H.B.K.] Lag. Ex. Grimths). High and low shrub diets contained about $12 \%$ and $8 \%$ crude protein, respectively. Nitrogen retention did not differ $(P>0.05)$ among mountain mahogany and fourwing saltbush diets; however, goats fed the $60 \%$ shrub level had greater $(P<0.05)$ nitrogen retention than did those fed the $30 \%$ level. Mountain mahogany diets had a greater soluble phenolic/tannin content than fourwing saltbush diets, but this did not appear to influence nitrogen retention. Forage organic matter intakes averaged $2.0 \%$ of body weight and did not differ $(P>0.05)$ among the 4 treatments. Total fecal output of nitrogen $(g / d)$ was highly correlated $\left(r^{2}=.71, n=15\right)$ with nitrogen retention. Hence, total fecal nitrogen output may be useful as an indicator of grazing ruminant protein status. Digestible protein (\%) and dietary crude protein concentrations were associated poorly with nitrogen retention in our study. Blood serum analysis showed no toxicosis problem for any of the 4 dietary treatments. We concluded that leaves from fourwing saltbush and true mountain mahogany have potential to be an effective source of protein for range livestock consuming low-quality grasses.

\section{Key Words: rangelands, ruminants, grazing, forage}

Fourwing saltbush (Atriplex canescens [Pursh.], Nutt.) and true mountain mahogany (Cercocarpus montanus Raf.) are evergreen shrubs that occur throughout the western United States. Both shrubs are palatable to livestock and big game animals. NunezHernandez et al. (1989) found that nitrogen retention and forage intake by goats consuming mixtures containing these shrubs equaled or exceeded those by goats fed a mixture containing alfalfa (Medicago sativa L.) hay. In their study, all 3 forage species were fed at $30 \%$ (dry matter basis) of the diet in a low-quality barley straw-prairie hay mixture, and crude protein levels of the 3 diets were about $9 \%$. Although Nunez-Hernandez et al. (1989) showed that fourwing saltbush and mountain mahogany fed at low levels enhanced nutritional status of goats consuming a low-quality grass diet, the effects of these shrubs at greater percentages of the diet are uncertain.

Compared with mountain mahogany, leaves of fourwing saltbush have more crude protein and less fiber at comparable stages of maturity (Cordova and Wallace 1975, Nunez-Hernandez et al. 1989). However, mountain mahogany has elevated levels of soluble phenolic compounds (Nunez-Hernandez et al. 1989) that may reduce nitrogen digestibility and retention (Mould and Robbins 1981, Nastis and Malechek 1981). This effect was minor in the study of Nunez-Hernandez et al. (1989), but it could be important if higher levels of mountain mahogany were included in the diet.

\footnotetext{
Authors are graduate research assistant, professors, and graduate research assistant, Department of Animal and Range Sciences; and professor, Department of Experimental Statistics, New Mexico State University, Las Cruces, New Mexico.

Journal Article 1482 of the New Mexico Agr. Exp. Sta., Las Cruces.

Manuscript accepted 8 March 1990.
}

The objectives of our research were to evaluate effects of fourwing saltbush and true mountain mahogany on nitrogen balance, intake and digestibility by Angora goats when fed at 2 dietary levels (30 and 60\%) with blue grama (Bouteloua gracilis [H.B.K.] Lag. ex Griffiths) hay. A secondary objective was to determine, through blood serum analyses, if toxicosis was evident with either of these 2 shrubs.

\section{Materials and Methods}

Branches of mountain mahogany and fourwing saltbush were collected near the Organ Mountains in northcentral New Mexico during August 1988. After air drying for 5 to 6 days, leaves were collected and stored. Daytime drying temperatures were between $26^{\circ}$ and $38^{\circ} \mathrm{C}$. In all cases, collected plant material consisted of current year's annual growth of leaves. Four diets were formulated consisting of 2 levels (30\% and $60 \%$ of air-dry weight) of fourwing saltbush and true mountain mahogany leaves with prairie hay as the basal feed. The prairie hay consisted mainly of blue grama (Bouteloua gracilis [H.B.K.] Lag. ex. Griffiths) cut as it neared maturity. Because the shrub leaves were small, they were mixed whole with blue grama hay that had been chopped through a $5-\mathrm{cm}$ screen. Chemical composition of these forages is shown in Table 1.

Table 1. Chemical composition of mountain mahogany, fourwing saltbush and blue grama prairie hay.'

\begin{tabular}{lccc}
\hline & \multicolumn{3}{c}{ Forages } \\
\cline { 2 - 4 } Constituents $^{2}$ & $\begin{array}{c}\text { Mountain } \\
\text { mahogany }\end{array}$ & $\begin{array}{c}\text { Fourwing } \\
\text { saltbush }\end{array}$ & $\begin{array}{c}\text { Blue grama } \\
\text { prairie hay }\end{array}$ \\
\hline DM,\% & 92.2 & 92.7 & 93.8 \\
OM,\% & 94.4 & 77.8 & 90.0 \\
N, \% & 1.9 & 2.0 & 0.8 \\
ADIN, \% & 0.3 & 0.1 & 0.2 \\
NDF, \% & 41.9 & 33.1 & 67.3 \\
ADF, \% & 24.8 & 16.6 & 41.5 \\
ADL, \% & 15.7 & 7.5 & 5.6 \\
EE, \% & 4.7 & 1.3 & 1.3 \\
T, mg/100 mg & 15.8 & 0.1 & 0.1 \\
P, mg/g & 124.4 & 16.1 & 16.6 \\
\hline
\end{tabular}

IValues for chemical composition were calculated using least square means, and are expressed on an organic matter basis.

2DM = Dry matter, OM = Organic matter, $\mathrm{N}=$ Total nitrogen, $\mathrm{ADIN}=$ Acid detergent insoluble nitrogen, $\mathrm{NDF}=$ Neutral detergent fiber, $\mathrm{ADF}=$ Acid detergent fiber, $\mathrm{ADL}$ = Acid detergent lignin, EE = Ether extract, $P=$ Phenolics, $T=$ Tannins.

A 20-day digestion trial using sixteen 1 to 2-year-old castrated male Angora goats $(33 \pm 9 \mathrm{~kg}$ ) reared on shrubland range in south central New Mexico was conducted in a temperature-controlled building at New Mexico State University during September, 1988. Goats were classified into 4 blocks of 4 goats with similar weights. Goats were sheared and wormed before the trial and also were weighed before and after the trial following a $12-\mathrm{h}$ fast.

A randomized block design was used with each of the 4 treatments being assigned randomly to the 4 goats in each block. Throughout the 20-day trial, the goats were housed in metabolism crates. Diets were offered during the first 5 days at a rate of $2.5 \%$ of body weight and then adjusted for 100 to $200 \mathrm{~g}$ of orts daily (Harris 1970). Feed was offered twice daily (0800 and 1700$)$. Subsamples of feed and orts were obtained during the last 5 days for chemical 
analyses. Feces were also collected during this period in fecal bags, weighed and a 30-g subsample was taken for each goat. Fecal samples were dried at $60^{\circ} \mathrm{C}$. Feed, orts, and feces were ground to pass a l-mm screen in a Wiley Mill. Urine volume was recorded daily and urine subsamples from each goat were frozen. Volatilization of ammonia from urine samples was prevented by adding 10 $\mathrm{ml}$ of $6.1 \mathrm{~N} \mathrm{HCl}$ to the collection vessel.

On the last day of the trial, blood was collected from the jugular vein of each goat into a serum separator tube. Blood samples were centrifuged immediately, and serum was sent to a commercial laboratory' ${ }^{1}$ for analysis of clinical chemistry profiles. Blood samples were evaluated for the serum glutamate oxaloacetate transaminase SGOT [AST], serum glutamic-pyruvic transaminase SGPT [ALT], lactic dehydrogenase (LDH), total bilirubin, direct bilirubin, indirect bilirubin, blood urea nitrogen (BUN), creatinine, and uric acid. These analyses were used to determine if the diets caused hepatic or renal dysfunctions.

Feed, orts, feces, and urine samples were subjected to chemical analyses (Tables 1 and 2). The dry matter, organic matter, total

Table 2. Chemical composition of diets consumed by Angora goats in the digestion trial.'

\begin{tabular}{|c|c|c|c|c|c|}
\hline \multirow{3}{*}{$\begin{array}{l}\text { Chemical }{ }^{2} \\
\text { constituents }\end{array}$} & \multicolumn{4}{|c|}{$\begin{array}{r}\text { Diets } \\
\end{array}$} & \multirow[b]{3}{*}{ SE } \\
\hline & \multicolumn{2}{|c|}{ M. Mahogany } & \multicolumn{2}{|c|}{ F. saltbush } & \\
\hline & $30 \%$ & $60 \%$ & $30 \%$ & $60 \%$ & \\
\hline OM, \% & 93.2 & 93.7 & 87.6 & 84.2 & 0.31 \\
\hline $\mathrm{N}, \%$ & 1.2 & 1.7 & 1.6 & 2.3 & 0.04 \\
\hline $\mathrm{ADIN}, \%$ & 0.2 & 0.3 & 0.2 & 0.2 & 0.01 \\
\hline NDF, $\%$ & 72.0 & 60.0 & 74.3 & 67.0 & 1.17 \\
\hline ADF, $\%$ & 45.3 & 38.7 & 43.5 & 37.2 & 0.79 \\
\hline $\mathrm{ADL}, \%$ & 11.5 & 11.9 & 9.1 & 10.4 & 0.92 \\
\hline $\mathrm{EE}, \%$ & 3.2 & 4.0 & 1.9 & 2.2 & 0.12 \\
\hline $\mathrm{T}, \mathrm{mg} / 100 \mathrm{mg}$ & 6.8 & 11.4 & 0.1 & 0.4 & 0.38 \\
\hline $\mathrm{P}, \mathrm{mg} / \mathrm{g}$ & 75.6 & 132.0 & 20.3 & 22.9 & 1.89 \\
\hline
\end{tabular}

IValues for chemical composition, expressed on an organic matter basis, were calculated using least squares means after adjusting for orts.

${ }^{2} \mathrm{DM}=$ Dry matter, $\mathrm{OM}=$ Organic matter, $\mathrm{N}=$ Total nitrogen, $\mathrm{ADIN}=$ Acid detergent insoluble nitrogen, $\mathrm{NDF}=$ Neutral detergent fiber, $\mathrm{ADF}=\mathrm{Acid}$ detergent fiber. ADL $=$ Acid detergent lignin, $\mathrm{EE}=$ Ether extract.

nitrogen and ether extract (EE) were determined according to standard procedures (AOAC 1984). Acid detergent fiber (ADF), acid detergent lignin (ADL), neutral detergent fiber (NDF) and acid detergent insoluble nitrogen (ADIN) were determined according to Goering and Van Soest (1970). Total phenolic content of feed and orts was determined using the Folin-Denis procedure (AOAC 1984). Tannin content of feed and orts was determined by the Vanillin/ $\mathrm{HCl}$ procedure (Burns 1971) as modified by Price et al. (1978). This procedure was chosen because it has been commonly used, and laboratory techniques are standardized. Mountain mahogany was high in phenolics and tannins, requiring a modification of the procedure. The sample used for analysis was $0.1 \mathrm{~g}$ for the mountain mahogany diet and $0.05 \mathrm{~g}$ for the $60 \%$ diet, instead of $0.5 \mathrm{~g}$ as recommended for the procedure. Chemical composition data for diets consumed by goats in the digestion trial are shown in Table 2.

Data were analyzed as a randomized block with a $2 \times 2$ factorial arrangement of treatments, with shrub species and level of shrub in the diets as main effects (Steel and Torrie 1980). One goat was removed from the $60 \%$ fourwing saltbush diet because of refusal to eat; hence, least square means (SAS 1984) were used for the analysis. Differences were considered significant at probabilities $\leq 0.05$. Simple regression and correlation analyses were performed to evaluate the relationships among nutritive value characteristics of

'Southwest Medical Laboratory, 755 Telshor Blvd., Las Cruces, NM 88001. Hitachi 705 Analyzer, Boehringer Manheim Diagnostics, Indianapolis, IN. diets. The General Linear Models procedure of SAS (1984) was used for regression analysis.

\section{Results and Discussion}

\section{Nitrogen Retention}

Main effects of shrub level and shrub species were significant for most nitrogen retention $(\mathrm{g} / \mathrm{d})$ characteristics (Table 3 ), but no interaction occurred between shrub species and level for the nitrogen characteristics evaluated. Nitrogen retention did not differ between mountain mahogany and fourwing saltbush diets; however, the $60 \%$ shrub level resulted in greater nitrogen retention than that of the $30 \%$ level. Nitrogen intake and nitrogen retention of mountain mahogany diets as percentages of those for fourwing saltbush diets, were $63 \%$ and $64 \%$, respectively, which shows that the proportion of nitrogen intake retained was the same for both shrubs. Hence, greater phenolic content of mountain mahogany compared with fourwing saltbush diets had no detrimental effect on nitrogen retention.

Table 3. Organic matter intake, in vivo organic matter digestibility and nitrogen utilization by Angora goats fed diets containing two different levels of leaves from mountain mahogany and fourwing salthush.

\begin{tabular}{|c|c|c|c|c|c|}
\hline \multirow[b]{2}{*}{ Items } & \multicolumn{2}{|c|}{ Shrub levels } & \multicolumn{2}{|c|}{ Shrub species } & \multirow[b]{2}{*}{ SE } \\
\hline & $30 \%$ & $60 \%$ & $\begin{array}{c}\text { M. } \\
\text { mahogany }\end{array}$ & $\begin{array}{c}\text { F. } \\
\text { saltbush }\end{array}$ & \\
\hline $\begin{array}{l}\text { Organic matter } \\
\text { intake, } \% \text { BW }\end{array}$ & 1.9 & 2.2 & 2.0 & 2.1 & 0.21 \\
\hline $\begin{array}{l}\text { Digestible organic } \\
\text { matter intake, } \\
\% \mathrm{BW}\end{array}$ & 1.0 & 1.2 & 1.1 & 1.1 & 0.22 \\
\hline $\begin{array}{l}\text { In vivo organic } \\
\text { matter }\end{array}$ & & & 1.1 & & \\
\hline $\begin{array}{l}\text { digestibility, } \% \\
\text { Crude protein. }\end{array}$ & 52.3 & 54.2 & 54.2 & 52.2 & 0.50 \\
\hline$\%$ of diet & 8.8 & 12.5 & 9.1 & 12.2 & 0.25 \\
\hline $\mathrm{N}$ intake, $\mathrm{g} / \mathrm{d}$ & $8.5^{\mathrm{a}}$ & $13.9^{\mathrm{b}}$ & $8.9^{a}$ & $13.6^{\mathrm{b}}$ & 1.28 \\
\hline Digestible N, g/d & $5.2^{\mathrm{n}}$ & $9.2^{\mathrm{b}}$ & $4.9^{\mathrm{n}}$ & $9.4^{\mathrm{b}}$ & 0.81 \\
\hline Fecal $N, g / d$ & 3.4 & 4.7 & 4.0 & 4.1 & 0.50 \\
\hline Urinary $\mathbf{N}, \mathbf{g} / \mathrm{d}$ & 5.2 & 6.8 & $4.0^{\mathrm{a}}$ & $8.0^{b}$ & 0.67 \\
\hline Retained N, g/d & $-0.1^{a}$ & $2.4^{\mathrm{b}}$ & 0.9 & 1.4 & 0.39 \\
\hline
\end{tabular}

${ }_{a, b}$ Mean values within class (levels or species) with different superscripts differ $(P<0.05)$.

Nunez-Hernandez et al. (1989) found that goats fed diets containing gray oak (Quercus grisea Liebm.), one- seed juniper (Juniperus monosperma [Engelm]. Sarg.), and true mountain mahogany had nitrogen retention values equal to or greater than those of the diets containing alfalfa (Medicago sativa L.) at a similar crude protein content. Our study is consistent with Nastis and Malechek(1981), Sidahmed et al. (1981), and Nunez-Hernandez et al. (1989) in showing that high levels of soluble phenolics/tannins do not necessarily result in reduced nitrogen retention by goats. These studies all show that nitrogen retention is more a function of nitrogen intake than nitrogen digestion. Coefficients of determination between nitrogen retention and nitrogen intake were .90 for Sidahmed et al. (1981), .81 for Nastis and Malechek (1981), .62 for Nunez-Hernandez et al. (1989) and .61 for the present study. Thus, the primary effect of high phenolic/tannin shrubs on goat nitrogen status may be through reduced forage intake and possible toxicosis, rather than reduced nitrogen retention.

Nitrogen balance was near zero for $30 \%$ shrub diets. The dietary crude protein and intake levels on an OM basis for $30 \%$ shrub diets were $8.75 \%$ and $1.9 \%$ body weight, respectively. Forage intake of sheep dropped when dietary crude protein levels fell below $8 \%$ (OM basis) or 7\% (DM basis; Milford and Minson 1965). Crude protein concentrations below these levels may not meet the needs 


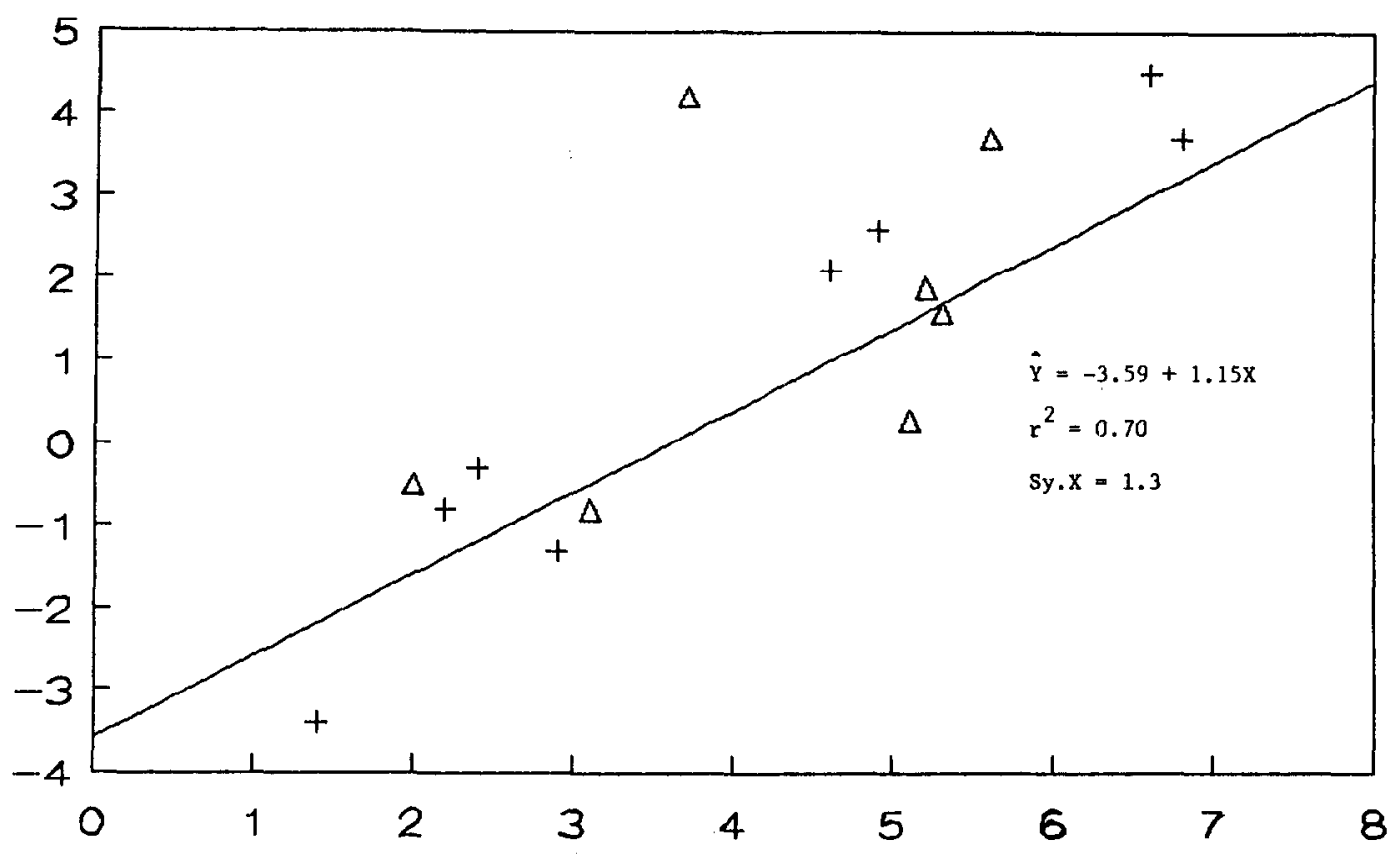

Fig. 1. Relationship between apparent retained nitrogen $(g / d)$ and total fecal nitrogen (g/d) output for all diets.

of ruminal bacteria or of the host ruminant.

Nunez-Hernandez et al. (1989) found that Angora goats were in positive nitrogen balance when nitrogen consumption exceeded $.24 \mathrm{~g} \mathrm{~N} / \mathrm{kg} \mathrm{BW}$ daily. In our study, goats fed the $30 \%$ shrub diet had a near zero nitrogen balance at a nitrogen intake of $.26 \mathrm{~g} \mathrm{~N} / \mathrm{kg} \mathrm{BW}$. In contrast Sidahmed et al. (1981) reported that Spanish goats consuming shrub diets were in positive nitrogen balance when they consumed $.42 \mathrm{~g} \mathrm{~N} / \mathrm{kg} \mathrm{BW}$ daily or more. Differences in methodologies and shrub species between studies could account for these differences. Methodology in our study was the same as in the Nunez-Hernandez et al. (1989) study.

Drying can cause phenolic/tannin compounds to be less harmful by reducing their solubility (Price et al. 1979). However, recent research indicates that drying has minor influences on phenolic/tannin solubility and subsequent protein digestion by ruminants (Robbins et al. 1987).

Our study shows more loss of nitrogen in the urine and less in the feces as a percentage of nitrogen intake for the high shrub compared to the low shrub diet. This also was true for fourwing saltbush relative to mountain mahogany diets. These data are consistent with the theory (Van Soest 1982) that ruminant urinary nitrogen losses relative to fecal nitrogen losses increase when dietary crude protein concentrations exceed $9 \%$ (OM basis), and explains why fecal nitrogen concentration loses reliability as an indicator of grazing ruminant protein status when dietary crude protein concentrations exceed $10 \%$ (OM basis; Wofford et al. 1985, Hakkila et al. 1988).

Stage of maturity, shrub species and shrub level in the diet all influence intake and potential toxicity (Nastis and Malechek 1981, Sidahmed et al. 1981). Phenolic/tannin subtances involve several sub-groups of compounds that have differing effects on forage palatability and toxicity (Rhoades and Cates 1976, Welch et al. 1983, Personius et al. 1987). The effects of phenolics and tannins on ruminants may be manifested through digestion, palatability and/or toxicosis. The experimentalist not only has the problem of separating these effects from one another, but also of separating these effects from those resulting from drying and grinding or pelleting. Prepared rations have been used in available studies involving phenolic/tannin influences, which may give different results than would occur under field conditions. Research is needed to determine how ration preparation influences results from the type of study we have conducted.

\section{Evaluation of Nitrogen Status}

Total daily fecal nitrogen was the best indicator of nitrogen retention in our study (Table 4; Fig. 1). This agrees with Stallcup et

Table 4. Simple linear regression equations relating dietary and fecal nitrogen characteristics to apparent nitrogen retention of Angora goats.

\begin{tabular}{lccccc}
\hline \hline Variables $^{1}$ & $\mathrm{a}$ & $\mathrm{b}$ & $\mathrm{r}^{2}$ & RSMSE & $\mathrm{n}$ \\
\hline N intake, g/d & -2.75 & 0.35 & $0.61^{*}$ & 1.525 & 15 \\
Crude protein, \% & -4.80 & 3.65 & 0.35 & 2.004 & 15 \\
Digestible N, \% & -2.08 & 3.19 & 0.24 & 2.132 & 15 \\
Fecal N, g/d & -3.59 & 1.15 & $0.70^{*}$ & 1.345 & 15 \\
Fecal N, \% & -8.77 & 7.49 & $0.28^{*}$ & 2.081 & 15 \\
Urinary N, g/d & 0.64 & 0.09 & 0.01 & 2.434 & 15 \\
\hline
\end{tabular}

iN = Nitrogen

*Variables are significantly correlated $(P<0.05)$.

$a=$ Intercept of the regression equation.

$b=$ Slope of the regression equation.

$r^{2}=$ Coefficient of determination

$r=$ Coefficient of correlation.

RSMSE = Root square MSE.

al. (1975), who reported a high coefficient of determination $\left(r^{2}=\right.$ .96) between total nitrogen intake and total fecal nitrogen output with 58 different forages fed to growing Holstein steers. In our study, total fecal nitrogen output was more highly correlated with 


$$
+ \text { Mountain Mahogany Diets }\left(\hat{Y}_{1}\right) \quad O \quad \text { Fourwing saltbush diets }\left(\hat{Y}_{2}\right)
$$

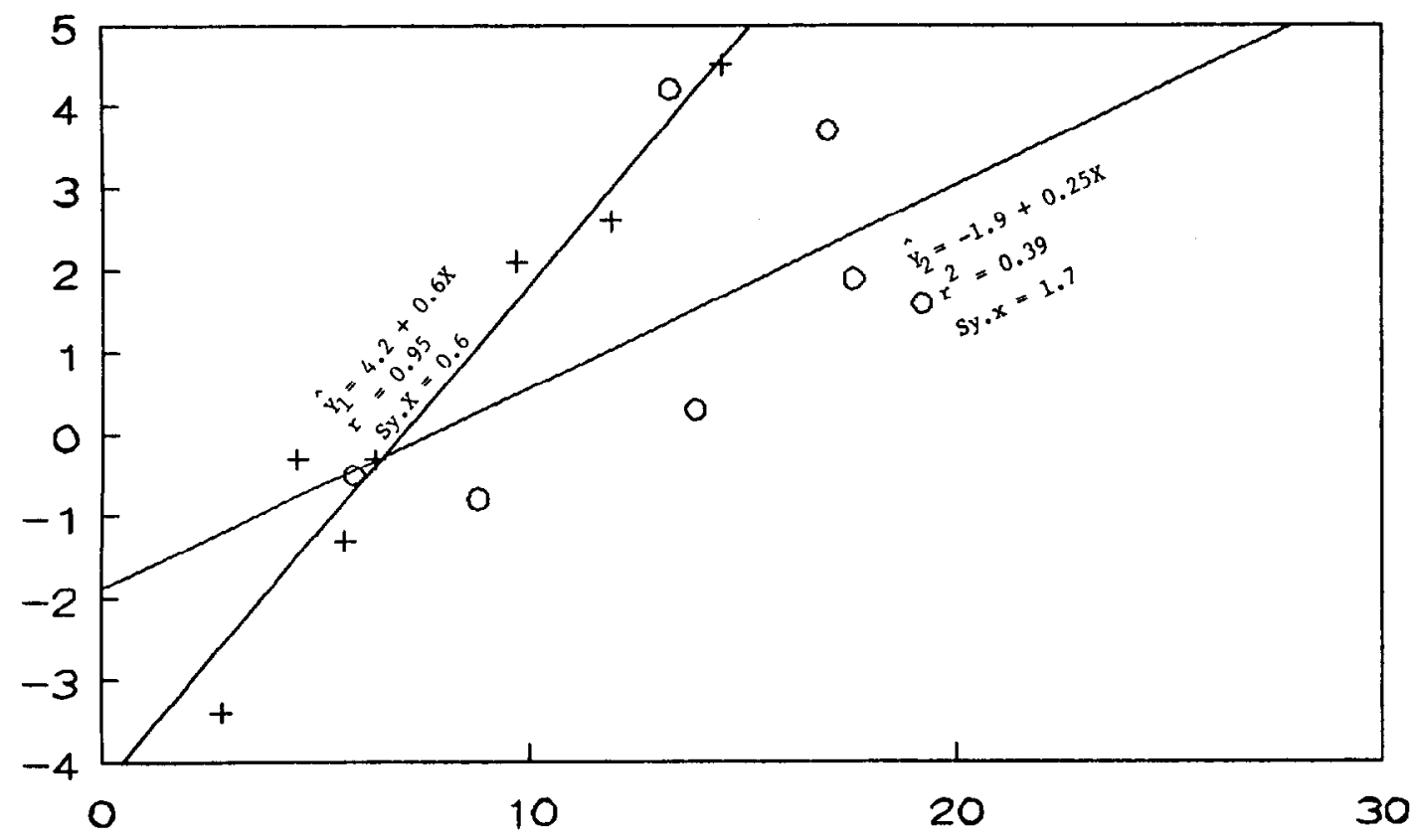

Fig. 2. Relationship between apparent retained nitrogen $(g / d)$ and nitrogen intake (g/d).

nitrogen retention than was nitrogen intake (Fig. 2). The regression equations for fourwing saltbush and mountain mahogany diets differed for nitrogen retention versus nitrogen intake but not for nitrogen retention versus fecal nitrogen output (Fig. 1 and 2). Our study involved only a limited number of feeds and it is quite possible Table 4 results are diet-specific relations that may not be applicable elsewhere. Total fecal nitrogen output has not been used as an indicator of protein status of ruminants grazing on rangelands; however, it can be evaluated through either total fecal collection (Stallcup et al. 1975, Holechek et al. 1986) or through external markers (Pond et al. 1987). Total fecal nitrogen output may have potential as a future measure of grazing ruminant protein status.

Our study and Nunez-Hernandez et al. (1989) both show that dietary crude protein percentage is not highly associated $\left(r^{2}<.36\right)$ with nitrogen retention when goats consume mixtures of grasses, forbs, and shrubs. Dietary crude protein percentage has been used extensively as an indicator of range ruminant protein status in previous studies (Holechek et al. 1989). However, when animals consume diets with forages other than grasses, it may be misleading as to true ruminant nitrogen status.

Digestible protein concentration has been suggested as a useful measure of grazing ruminant protein status (Raleigh 1970, Robbins et al. 1987). However, our study and that of Nunez-Hernandez et al. (1989) show that nitrogen retention is associated poorly with percentage digestible protein when ruminants consume diets containing mixtures of grasses, forbs, and shrubs. This is because urinary nitrogen losses show considerable variation among different isonitrogenous feeds, particularly when browse is included in the diet (Nastis and Malechek 1981, Rafique et al. 1988, NunezHernandez et al. 1989).

\section{Intake and Digestibility}

Organic matter intake and in vivo digestibility did not differ between shrub levels or species (Table 3). Values are nearly the same as those reported by Nunez-Hernandez et al. (1989) for alfalfa, fourwing saltbush and mountain mahogany mixtures similar in quality to those of the $30 \%$ shrub diets in our study. It appears that high levels of fourwing saltbush and mountain mahogany in goat diets have no adverse effects on digestibility and intake.

\section{Blood Serum Analyses}

Blood serum analyses revealed no toxicosis from any of the treatments (Table 5). All values in Table 5 are within the normal range for goats (Cole 1986). Nastis and Malechek (1981) reported no evidence of toxicosis when goats were fed diets containing $40 \%$ and $80 \%$ Gambel oak (Quercus gambelii Nutt.). Davis et al. (1975) found that free-ranging goats did not suffer from toxicosis when

Table 5. Serum biochemical constituents of Angora goat fed diets containing two different levels of browse leaves.

\begin{tabular}{|c|c|c|c|c|c|}
\hline \multirow[b]{2}{*}{ Serum constituents } & \multicolumn{2}{|c|}{ Shrub levels } & \multicolumn{2}{|c|}{ Shrub species } & \multirow[b]{2}{*}{ SE } \\
\hline & $30 \%$ & $60 \%$ & $\begin{array}{c}\text { M. } \\
\text { mahogany }\end{array}$ & $\begin{array}{c}\text { F. } \\
\text { saltbush }\end{array}$ & \\
\hline Creatinine, $\mathrm{mg} / \mathrm{dl}$ & 0.98 & 0.92 & 1.05 & 0.85 & 0.06 \\
\hline $\begin{array}{l}\text { Uric acid, mg/dl } \\
\text { Total bilirubin }\end{array}$ & 0.45 & 0.43 & 0.46 & 0.42 & 0.02 \\
\hline $\begin{array}{l}\mathrm{mg} / \mathrm{dl} \\
\text { Direct bilirubin, }\end{array}$ & 0.23 & 0.23 & $0.25^{\mathrm{a}}$ & $0.20^{\mathrm{b}}$ & 0.01 \\
\hline $\begin{array}{l}\mathrm{mg} / \mathrm{dl} \\
\text { Indirect bilirubin, }\end{array}$ & 0.03 & 0.02 & 0.03 & 0.02 & 0.01 \\
\hline $\mathrm{mg} / \mathrm{dl}$ & 0.18 & 0.21 & 0.20 & 0.19 & 0.02 \\
\hline LDH; U/liter & 226.38 & 224.13 & 219.13 & 231.38 & 16.59 \\
\hline SGOT, U/liter & 61.13 & 63.26 & 62.25 & 62.14 & 5.45 \\
\hline SGOT, U/liter & 11.38 & 13.07 & 12.75 & 11.69 & 1.80 \\
\hline
\end{tabular}

a,b Mean values with different superscripts differed $(P<0.05)$.

LDH = Lactic dehydrogenase, SGOT = Serum glutaminoxaloacetic transaminase, SGPT = Serum glutamic-pyruvic transaminase. 
they consumed up to $85 \%$ shrubs in the diet. It should be noted that trial length in our study may have been too short for manifestation of toxic effects.

\section{Management Implications}

This study is consistent with other recent research (Rafique et al. 1988, Arthun et al. 1988, Nunez-Hernandez et al. 1989) in showing that leaves from palatable native shrubs can be an effective protein supplement for range livestock consuming low-quality grass diets. Concerns that elevated levels of soluble phenolic/tannin compounds and greater lignification associated with shrubs may reduce nitrogen availability and retention appear unwarranted under the conditions of these experiments. Palatable, nontoxic shrubs such as fourwing saltbush and true mountain mahogany appear to equal alfalfa hay as a source of protein for grazing ruminants. Under our conditions, goats consumed high levels (60\%) of these shrubs with no adverse effects; however, research on how high shrub levels effect the nutritional status of grazing cattle and sheep are lacking. The inclusion of fourwing saltbush and true mountain mahogany in mixtures with low-quality grasses can provide adequate $\mathbf{N}$ and $\mathrm{OM}$ intake for goats where these shrubs are adapted; these shrubs would be of greatest benefit during the dormant season in most situations.

\section{Literature Cited}

AOAC. 1984. Official methods of analyses (14th ed.). Assoc. Agr. Chem., Washington D.C.

Arthun, D., S. Rafique, J.L. Holechek, J.D. Wallace, and M.L. Galyean. 1988. Effects of forb and shrub diets on ruminant nitrogen balance II. Cattle studies. Proc. West. Sec. Amer. Soc. Anim. Sci. 39:204-207.

Burns, R.E. 1971. Method for estimation of tannin in grain sorghum. Agron. J. 63:511-512.

Cole, E.H. 1986. Veterinary clinical pathology. Fourth Ed. W.B. Saunders Co., New York.

Cordova, F.J., and J.D. Wallace. 1975. Nutritive value of some browse and forb species. Proc. West. Sec. Amer. Soc. Anim. Sci. 26:160-162.

Davis, E.G., L.E. Bartel, and C.W. Cook. 1975. Control of Gambel oak sprouts by goats. J. Range Manage. 26:216-218.

Goering, H.K., and P.J. Van Soest. 1970. Forage fiber analyses (apparatus, reagents, procedures, and some applications). USDA-ARS Handbook 379.

Hakkila, M., J.L. Holechek, J.D. Wallace, D.M. Anderson, and M. Cardenas. 1988. Fecal indicators of cattle protein status on desert grassland range. Nut. Rep. Internat. 37:137-147.

Harris, L.E. 1970. Nutrition Research. Techniques for Domestic and Wild Animals. L.E. Harris Publ., Utah State Univ., Logan.

Holechek, J.L., H. Wofford, D. Arthun, M.L. Galyean, and J.D. Wallace. 1986. Evaluation of total fecal collection for measuring cattle forage intakes. J. Range Manage. 39:2-4.

Holechek, J.L., R.D. Pieper, and C.H. Herbel. 1989. Range management principles and practices. Prentice Hall Publ. Co., Englewood Cliffs, N.J.
Milford, R., and D.J. Minson. 1965. Intake of tropical pasture species. Proc. Internat. Grassl. Congr. 9:815-822.

Mould, E.D., and C.T. Robbins. 1981. Nitrogen metabolism in elk. J. Wildl. Manage. 45:323-334.

Nastis, A.S., and J.C. Malechek. 1981. Digestion and utilization of nutrients in oak browse by goats. J. Anim. Sci. 53:283-289.

Nunez-Hernandez, G., J.L. Holechek, J.D. Wallace, M.L. Galyean, A. Tembo, R. Valdez, and M. Cardenas. 1989. Influence of native shrubs on nutritional status of goats: nitrogen retention. J. Range Manage. 42:228-232.

Personius, T.L., C.L. Wambolt, J.R. Stephens, and R.G. Kelsey. 1987. Crude terpenoid influence on mule deer preference for sagebrush. $\mathbf{J}$. Range Manage. 40:84-88.

Pond, K.P., J.C. Burns, and D.S. Fisher. 1987. External markers-use and methodology in grazing studies. In: Proc. Grazing I ivestock Nutrition Conf., Univ. Wyoming, Laramie.

Price, J.L., A.M. Stromberg, and L.G. Butler. 1979. Tannin content as a function of grain maturity and drying conditions in several varieties of Sorghum bicolor. J. Agr. Food Chem. 57:1270-1274.

Price, M.L., S. Van Scoyoc, and L.G. Butler. 1978. A critical evaluation of vanillin reaction as an assay for tannin in sorghum grain. J. Agr. Food Chem. 26:1214-1218.

Rafique, S., D. Arthun, M.L. Galyean, J.L. Holechek, and J.D. Wallace. 1988. Effects of forb and shrub diets on ruminant nitrogen balance. I. Sheep Studies. Proc. West. Sec. Amer. Soc. Anim. Sci. 39:200-203.

Raleigh, R.J. 1970. Symposium on pasture methods for maximum production in beef cattle manipulation of both livestock and forage management to give optimum production. J. Anim. Sci. 30:108-114.

Rhoades, D.F., and R.G. Gates. 1976. Toward a general theory of plant antiherbivore chemistry. p. 168-213. In: J.W. Wallace and R.L. Mansele (Eds.) Recent advances in phytochemistry, Vol. 10. Biochemical interaction between plants and insects. Plenam, New York.

Robbins, C.T., T.A. Hanley, A.E. Hagerman, O. Hjelford, D.L. Baker, C.C. Schwartz, and W.W. Mantz. 1987. Role of tannins in defending plants against ruminants: Reduction in protein availability. Ecology. 68:98-107.

SAS. 1984. SAS User's Guide, Statistics. SAS Inst., Inc., Cary, N. C.

Sidahmed, A.E., J.G. Morris, L.J. Koong, and S.R. Radosevich. 1981. Contribution of mixtures of three chaparral shrubs to the protein and energy requirements of Spanish goats. J. Anim. Sci. 53:1391-1396.

Stallcup, O.T., G.V. Davis, and L. Shields. 1975. Influence of dry matter and nitrogen intakes on fecal nitrogen losses. J. Dairy Sci. 58:1301-1311.

Steel, R.G.D., and J.H. Torrie. 1980. Principles and procedures of statistics. 2nd Ed. McGraw-Hill Book Co., Inc., New York.

Tilley, J.M.A., and R.A. Terry. 1963. A two stage technique for the in vitro digestion of forage crops. J. Brit. Grassl. Soc. 18:401-411.

Van Soest, P.J. 1982. Nutritional ecology of the ruminant. O \& B Books Inc., Corvallis, Ore.

Welch, B.L., E.D. McArthur, and J.N. Davis. 1983. Mule deer preference and monoterpenoids (essential oils). J. Range Manage. 36:485-487.

Wofford, H., J.L. Holechek, M.L. Galyean, J.D. Wallace, and M. Cardenas. 1985. Evaluation of fecal indices to predict cattle diet quality. J. Range Manage. 38:450-454. 